\title{
Mucocele Frontal Unilateral Gigante: Relato De Caso Giant Unilateral Frontal Mucocele: Case Report
}

\author{
Fazoli F ${ }^{1}$, Beller GR ${ }^{1}$, Bahls JH ${ }^{1}$ and Nakamura $\mathrm{KH}^{2}$ \\ ${ }^{1}$ Department of Neurosrgery, Hospital Santa Casa de Maringa Maringa, Brazil \\ ${ }^{2}$ Department of Neurosurgery, Universidade Estadual de Londrina, Brazil
}

Submission: October 14, 2016; Published: November 05, 2016

*Corresponding author: Fazoli F, Department of Neurosurgery, Hospital Santa Casa de Maringa, Maringa, Brazil, Tel: +554499270996,

Email: fazolifranciele@gmail.com

\begin{abstract}
Mucoceles result from mucus and secretion accumulation inside cavities. The external expansion of frontal sinuses mucoceles leads to local swelling with a soft and poorly defined mass on palpation and also headaches, edema, seizures and ophthalmopathy. This article reports a case of gigant unilateral frontal mucocele in a 62-year-old man, with good therapeutical. The empyema was drained followed by marsupialization and reconstruction of the right orbital roof and periorbital region with a titanium mesh to achieve acceptable cosmetic results and protect the brain tissue. The option was for an open surgical approach with excellent postoperative clinical progress and symptom resolution.
\end{abstract}

Keywords: Mucocele; Proptosis; Open sinus surgery

\section{Introduction}

Mucoceles result from mucus and secretion accumulation inside cavities, such as the paranasal sinuses, when inflammatory, infectious, traumatic or surgical processes obstruct their drainage pathways. A mucocele with infected mucus content is called mucopyocele [1-5]. The slow expansion of the mucusfilled mass compresses the cavity leading to a gradual rarefying osteitis of the paranasal sinuses walls and subsequently extension of the mass outside of the sinuses [3]. Frontal sinuses mucoceles can affect the skull base causing meningitis, meningoencephalitis, pneumocephalus, cerebral abscess, extraaxial collections or cerebrospinal fluid (CSF) $[1,4,6,7]$. The external expansion of frontal sinuses mucoceles leads to local swelling with a soft and poorly defined mass on palpation and also exophthalmos, proptosis, diplopia, headaches, edema, seizures, ophthalmopathy and amaurosis $[1,3,8]$.

Mucoceles are located in the frontal sinuses in $60 \%$ of cases, $25 \%$ are in the ethmoidal sinuses and $10 \%$ in the maxillary sinuses [4]. The majority of frontal sinuses mucocele cases are unilateral and bilateral mucoceles are rare [2]. Mucoceles are seen in adults of both sexes, usually between the fourth and seventh decade of life, and rarely in children under 10 years of age $[1,9]$. The usual mucocele needle aspiration findings are a large amount of proteinaceous fluid, with a varying amount of inflammatory cells and sometimes squamous or columnar epithelial cells [4]. The diagnosis is confirmed on radiologic imaging, with bone wall erosion and septal destruction. The main differential diagnosis is neoplasm [3]. Concentric bone remodeling is the typical computed tomography (CT scan) finding of mucoceles. On magnetic resonance imaging (MRI), there is hyperintense signal in $\mathrm{T} 2$ and rim enhancement following contrast injection [4]. The MRI yields better quality anatomical details potentially facilitating the diagnosis [1]. Surgical removal with osteoplastic technique is one of the available management options [3]. Endoscopic marsupialization has shown good results, with low morbidity and a less invasive surgical access, increasingly becoming the approach of choice. The main downside is a higher relapse rate $[4,10]$. In selected cases, the combined technique with open and endoscopic approaches has also shown good results with no relapse [10].

\section{Case Presentation}

A 62-year-old man presented to a university hospital emergency department with a 4-month history of right periorbital swelling. Past medical history revealed long term smoking and alcoholism. Physical examination confirmed a right frontal-orbital fluctuating mass, inferolateral deviation of the eye, and palpebral eversion. The CT scan of the face showed 


\section{Open Access Journal of Neurology \& Neurosurgery}

a large (8 $\mathrm{cm}$ in the long axis), infiltrative, hypodense and homogeneous mass with rim enhancement following contrast injection, located in the soft tissues of the right frontal region surrounding and deviating the eye laterally. There were signs of frontal bone osteolysis with extensive compromise of the ethmoidal cells and right frontal lobe. The CT scan of the head revealed a right frontal sinus homogeneous, lobulated, welldefined mass with soft tissue enhancement and significant compression and bone remodeling of the frontal sinus wall, right orbit and ethmoid bone. The mass measured 7.4 X $7.8 \times 5 \mathrm{~cm}$ in the longer axes, with an extra-axial intracranial component compressing and deviating brain tissue in the right frontal region causing parenchymal edema.

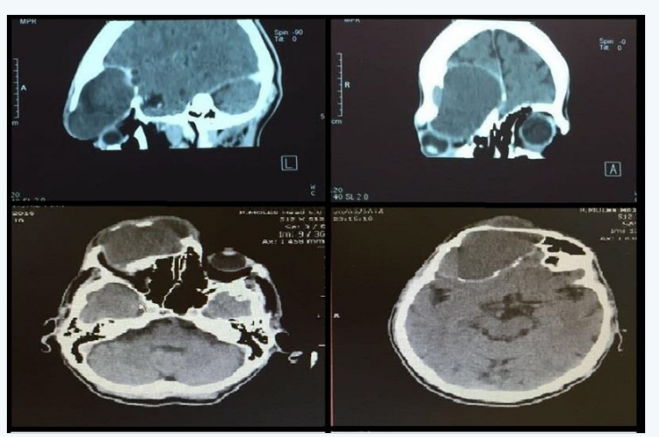

Figure 1: Computed tomography of the head.

Other findings were significant right orbital deformity with compression and infero-lateral deviation of the right eye with grade I proptosis (Figure 1). The preoperative differential diagnoses were right frontal sinus mucocele, right craniofacial neoplasm and mucopyocele. The surgical plan consisted of an bicoronal incision to allow ample surgical exploration of the mass. Intraoperatively, the findings included right frontal bone erosion expanding all the way into the right orbital roof with a non-septated, mucoid green fluid collection. Following the right orbital craniotomy, it was observed that the collection extended intracranially, with a fibroid capsule adhered to the meninges and septated epidural empyema (Figure 2).

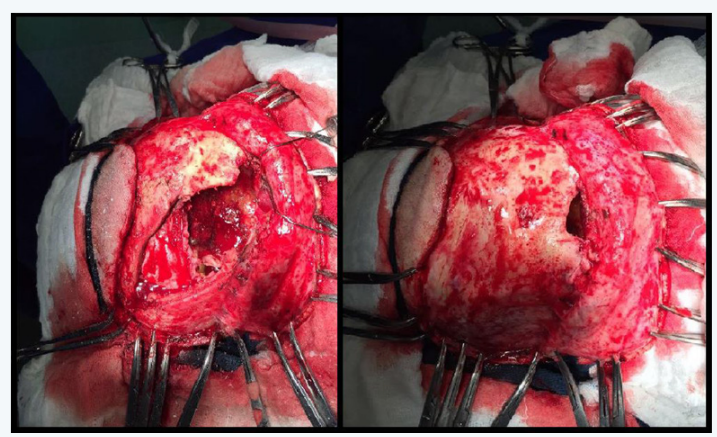

Figure 2: Right: Before craniotomy; Left: After craniotomy and drainage.

The empyema was drained followed by marsupialization and reconstruction of the right orbital roof and periorbital region with a titanium mesh to achieve acceptable cosmetic results and protect the brain tissue (Figure 3 ). The patient was started on clindamycin $600 \mathrm{mg}$ every 6 hours and ceftriaxone $2 \mathrm{~g}$ every 12 for 4 weeks. Histopathology results showed fragments of fibrous connective tissue lined by flat and stratified ciliated cuboidal epithelium with no atypia, mucin producing cells, moderate stromal inflammatory infiltrate, acute foci, hemosiderin pigments, cholesterol clefts with foreign-body giant cell reaction, and no malignant signs. Grocott stain was negative for fungi and the Ziehl-Nielsen stains were negative for acid fast bacilli. The mucocele fluid cultures were negative.

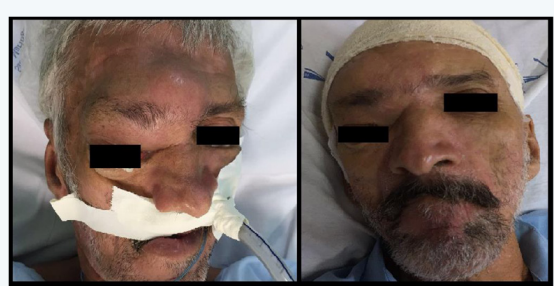

Figure 3: Right: Before surgery; Left: Early after surgery.

\section{Discussion}

The clinical history, physical examination, imaging and histopathology findings confirmed the diagnosis of unilateral right frontal sinus mucocele with intracranial extension. On postoperative follow-up the patient did not present any further complaints of headache, had a marked improvement of the orbital deformities, proptosis and diplopia. No relapse was identified up to the six-month follow-up appointment (Figure 4). We opted for a bicoronal open access technique to surgically remove the mucocele and reconstruct the frontal bone with good aesthetic results and protection of brain tissue as previously described in the literature [1,11-13]. Cranial bones infection can be hematogeous (blood-borne pathogens), however the majority of cases are caused by contiguous infected tissues and can extend to the meninges and adjacent soft tissues [12,14-17]. The patient in this case-report received 4 weeks of antibiotics without surgical site infections during the follow-up.

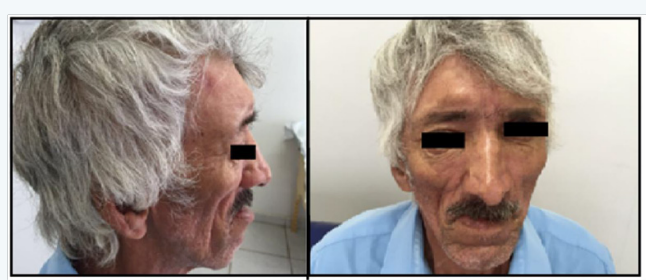

Figure 4: Six-month follow-up appointment.

\section{Conclusion}

Mucoceles should be included in the differential diagnosis for facial masses located in the paranasal sinuses region. In this case of a male adult presenting with unilateral giant frontal mucocele with intracranial extension the option was for an open 
surgical approach with excellent postoperative clinical progress and symptom resolution.

\section{References}

1. Cagigal BP, Lezcano JB, Blanco RF, Cantera JMG, Cuéllar LAS, et al. (2006) Frontal sinus mucocele with intracranial and intraorbital extension. Med Oral Patol Oral Cir Bucal 11(6): E527-E530.

2. Sakae FA, Bernardo Cunha Araújo Filho, Marcus Lessa, Richard Lois Voegels, Ossamu Butugan (2006) Bilateral Frontal Sinus Mucocele. Rev Bras Otorrinolaringol 72(3): 428

3. Hungria H (2000) Otorrinolaringologia. 8ed, Guanabara e Koogan, Rio de Janeiro, Brazil.

4. Neto CS, Da CSS, Garcia MRH (2011) Tratado De Otorrinolaringologia E Cirurgia Cervicofacial. 2ed, Roca, São Paulo, Brazil.

5. Junior SK, Amui gc, Acocella A, Mello EM, Oliveira RF, et al. (2005) Mucopiocele De Seio Frontal-Relato De Caso E Revisão De Literatura. IV Congresso triológico de otorrinolaringologia, São Paulo.

6. Britt RH, Enzmann DR (1983) Clinical stages of human brain abscesses on serial CT scans after contrast infusion. Computerized tomographic, neuropathological, and clinical correlations. J Neurosurg 59(6): 972 989

7. DE Falco R, Scarano E, Cigliano A, Russo G, Profeta L, Annicchiarico L, et al. (1996) Surgical Treatment of Subdural Empyema: A Critical Review. J Neurosurg Sci 40(1): 53-58.
8. Rowland LP, Pedley TA (2010) Merrit's Neurology. (12 ${ }^{\text {th }}$ edn), Editora Lippincott eillians e wilkins, Philadelfia, PA, USA.

9. Aydin E, Akkuzu G, Akkuzu B, Bilezikci B (2006) Frontal mucocele with an accompanying orbital abscess mimicking a fronto-orbital mucocele: case report. Bmc ear, nose and throat disorders 6: 6.

10. Godoy E, Godoy F (2006) Mucocele frontal lateral, tratamiento combinado endoscopico y externo. Caso clinico. Rev. Otorrinolaringol. Cir Cabeza Cuello 66: 147-153.

11. Bernardini GL (2004) Diagnosis and management of brain abscess and subdural empyema. Curr Neurol Neurosci Rep 4(6): 448-456.

12. Shmidek HH, Sweet WH (1995) Operative Neurosurgical Techniques: Indications, Methods and Results. ( $3^{\text {rd }}$ edn). Saunders, USA.

13. Srinivasa R, Dadlani D, Hegde As (2013) Incidental giant frontal ssinus mucocele with intracranial extension. Neurology India 61(4): 447-448.

14. Bannister G, Williams B, Smith S (1981) Treatment of subdural empyema. J Neurosurg 55(1): 82-88.

15. Helfgott DC, Weinggarten K, Hartman BJ (1991) Subdural Empyema. In: Scheld, Whitley, Durack (Eds), Infections of the Central Nervous System. Raven Press, New York, USA, pp. 487-498.

16. Courson AM, Stankiewicz JA, Lal D (2014) Contemporary management of frontal sinus mucoceles: a meta-analysis. Laryngoscope 124(2): 378-386.

17. Yap SK, Aung T, Yap EY (1998) Frontal sinus mucoceles causing proptosis-two case reports. Ann Acad Med Singapore 27(5): 744-747.

Your next submission with JuniperPublishers will reach you the below assets

- Quality Editorial service

- Swift Peer Review

- Reprints availability

- E-prints Service

- Manuscript Podcast for convenient understanding

- Global attainment for your research

- Manuscript accessibility in different formats ( Pdf, E-pub, Full Text, Audio)

- Unceasing customer service

Track the below URL for one-step submission http://juniperpublishers.com/online-submission.php 